\title{
MYCOPLASMAS IN PLAQUE AND SALIVA OF CHILDREN AND THEIR RELATIONSHIP TO GINGIVITIS
}

Type: Article

Abstract:

GINGIVITIS IS COMMON IN CHILDREN but its etiology is not well understood. Results of earlier studies have suggested that mycoplasmas may have a role in the disease. In this study two plaque samples and one stimulated saliva sample were taken from each of a group of sixty (60) 5 to 9 year-old children and cultured selectively for mycoplasmas. Subjects had been selected on the basis of gingival status buccal to the most posterior tooth in an upper quadrant, 20 each having scores 0,1 , or 2 at this site using the Loe and Silness index. Plaque samples were taken from the adjacent tooth surface and from a second posterior site where the adjacent gingiva was free of signs of inflammation. Mycoplasmas were cultured from 54 saliva samples and from 57 plaque samples. Isolation frequency and numbers of mycoplasmas in relation to total anaerobic counts were consistently related to gingivitis scores in both plaque and saliva samples, with higher frequencies and proportions with increasing levels of gingival inflammation at the selected site. In plaque samples this finding held good for both comparisons between groups of subjects and for those between test and control sites within subjects. Findings would appear to confirm the suggestions of earlier studies that mycoplasmas in the oral cavity are associated with gingivitis in children.

\begin{tabular}{|c|l|}
\hline Author & Holt, R. D. , Wilson, M. , Musa, S. \\
\hline Source & Journal of Periodontology \\
\hline ISSN & $0022-3492$ \\
\hline DOI & - \\
\hline Volume (Issue) & $66(2)$ \\
\hline Page & $97-101$ \\
\hline Year & 1995 \\
\hline
\end{tabular}

Keyword:

Children, gingivitis etiology, gingivitis microbiology, dental plaque, microbiology, saliva microbiology, periodontal-disease, bacteriology, health

Please Cite As:

HOLT, R. D., WILSON, M. \& MUSA, S. 1995. MYCOPLASMAS IN PLAQUE AND SALIVA OF CHILDREN AND THEIR RELATIONSHIP TO GINGIVITIS. Journal of Periodontology, 66, 97-101. 
URL:

- http://apps.webofknowledge.com >> Search via Web Of Science Accession No: A1995QG79800001

- http://www.ncbi.nlm.nih.gov/pubmed/7730969

- $\quad$ http://www.joponline.org/doi/abs/10.1902/jop.1995.66.2.97

- https://iris.ucl.ac.uk/research/browse/showpublication?pub id =114608\&source $\mathrm{id}=1$ 